\title{
A sertéshússal és a sertésből készült termékekkel kapcsolatos preferenciák vizsgálata egyetemista hallgatók körében
}

\section{Examination of Preferences for Pork Meat and Pork Meat Products among University Students}

\author{
O. B. NAGY
}

Debreceni Egyetem Ihrig Károly Gazdálkodás- és Szervezéstudományok Doktori Iskola, nagy.orsolya@econ.unideb.hu

\begin{abstract}
Absztrakt. A tanulmány célja a sertéshússal és a sertésből készült termékekkel kapcsolatos fogyasztói preferenciák vizsgálata volt. Az elemzéshez felhasznált minta (N=324) a Debreceni Egyetem Gazdaságtudományi Karának hallgatói köréből került kiválasztásra. A felmérés online kérdöíves formában zajlott le. Az adatok feldolgozásához leíró statisztikák, Khi-négyzet próbák, Spearman-féle rangkorreláció vizsgálatok, Mann-Whitney és Kruskal-Wallis próbák használata valósult meg. Az eredmények alapján elmondható, hogy a vizsgált mintában szereplő fogyasztók többsége, mindössze 50\% alatti összeggel lenne hajlandó többet fizetni a magyar és az egészségesebb termékekért. Az elemzések során szignifikáns eltérés született a férfiak és nők között minden vizsgálatba bevont a vásárlásnál figyelembe vett tényező tekintetében; a középfokú és a felsőfokú végzettséggel rendelkezők között a gyártó/márka megítélésében; a jövedelemkategória csoportoknál pedig az ár és az egészséges táplálkozás szerint.
\end{abstract}

Abstract. The purpose of this study was to examine the preferences for pork meat and pork meat products. The used sample $(N=324)$ for the analysis came from the students of the University of Debrecen Faculty of Economics and Business. The survey was conducted by the form of online questionnaire. The results from data analyzes were based on descriptive statistics, cross-table and correlation analysis, Mann-Whitney and Kruskal-Wallis tests. Based on the results we can concluded that majority of consumers in the sample would be willing to pay more for hungarian and healthier products with less than 50\%. Furthermore we can say that have a significant difference between men and women according all factors which used in analysis; have a significant difference between people with secondary and higher education according to perception of manufacturer/brand; have a significant difference between income level groups according to price and healthy eating.

\section{Bevezetés}

Mindennapjaink velejárója a döntéshozatal, melyet mint lehetőségek közötti választásként szokás definiálni. Ebből a viszonylag egyszerűnek hangzó megfogalmazásból is kiderül az, hogy a folyamat 
végén valamihez hozzájutunk, azonban ezzel egyidőben valamiről le is kell mondanunk. Az egyének napi szinten szembesülnek azzal a ténnyel, hogy különféle szükségleteik támadnak bizonyos termékek/szolgáltatások „elfogyasztására”, viszont ezek teljes kielégítésének gátat szab a közgazdaságtan szakirodalmában „alternatív költségként” definiált fogalom, amely a nem választott alternatívából származó hasznosságszintet jelenti. Ennek következtében a fogyasztóknak szubjektív értékítéleten alapuló rangsorokat kell képezniük, amelyek a preferenciákhoz vezetnek. Ahhoz, hogy megértsük a folyamatban rejlő szabályszerűségeket, a fogyasztói magatartás alapos vizsgálatára van szükség (Keeney-Raiffa, 1993; White, 2006; Boland, 2017; Mousavi, 2018; Sharma, 2018).

A fogyasztói magatartás vizsgálata egy rendkívül összetett folyamat, amelyet már számos szerző megpróbált leírni. Kotler négy fó csoportot (környezeti (kultúrák, társadalmi osztályok), társadalmi (család, státuszok), személyes jellemzők (életkor, végzettség, foglalkozás) és pszichológiai jellemzők (motiváció, attitűdök)) alakított ki, amelyek hatást gyakorolnak a fogyasztó döntéseire (Kotler, 1998). A különféle demográfiai jellemzőket számos tanulmányban sikeresen használták arra, hogy egyének csoportjait vizsgálják bizonyos termékek/szolgáltatások iránt mutatott preferenciáik alapján. Ezek közül több írásban is a fogyasztók különböző húsokra, hústermékekre vonatkozó preferenciáit kísérelték meg feltárni és elemezni (Aydogdu-Kucuk, 2018; Bernabéu et al., 2018; Demartini et al., 2018; Kiran et al., 2018; Merlino et al., 2018; Ngapo et al., 2018; Torrico et al., 2018; Udomkun et al., 2018; Wang et al., 2018; Lambooij et al., 2019).

\section{A sertéshús magyarországi helyzete}

Magyarországon az állattenyésztés jelentősége az Európai Uniós csatlakozást követően hanyatlásnak indult. A sertéságazatra az állatállomány folyamatos csökkenése jellemző. Míg 2004-ben 4,06 millió sertést tartottak az országban, addig 2018-ra a sertések száma 2,87 millió egyedre csökkent (KSH, 2019a). Ennek oka, hogy nagymértékben fokozódott a verseny, a termelőknek egyre szigorúbb állatjóléti és környezetvédelmi előírásoknak kellett megfelelniük, a vágóhidak számára pedig számos új beszerzési lehetőség nyílt, amelyekre a hazai termelők nem voltak felkészülve (Csonka, 2012).

A sertésállomány csökkenésének következtésben egyre nagyobb szerepe lett a sertéshús külföldről történő behozatalának. Míg 2004-ben még 60 ezer tonna volt a sertéshús import mennyisége, addig 2018-ra ez jelentős mértékben megnövekedett, mennyisége 171668 tonna lett (AKI, 2019). A sertéshús export is nőtt az Uniós csatlakozást követően, hiszen 2004-ben ennek mennyisége 81004 tonna volt, 2018-ra pedig már 133511 tonna lett (AKI, 2019).

Az egy főre jutó húsfogyasztás 2004-ben 60,9 kg volt (KSH, 2019b), melynek 45,5\%-a baromfihús (KSH, 2019c), 42,5\%-a sertéshús (KSH, 2019d), 12,0\%-a egyéb húsok. A Központi Statisztikai Hivatal legfrissebb adatai alapján pedig az egy fóre jutó húsfogyasztás mennyisége 71,2 kg (KSH, 2019b), melynek 47,1\%-a baromfihús (KSH, 2019c), 42,7\%-a sertéshús (KSH, 2019d), 10,3\%-a egyéb (marha, borjú, juh, stb.) húsok. A sertéshús tehát Magyarországon az egyik leggyakrabban fogyasztott húsféleségek közé tartozik. 
A kutatásom célja megvizsgálni, hogy mutatható-e ki eltérés bizonyos jellemzők (többnyire demográfiai tényezők) mentén, egyetemista hallgatók között, a sertéshússal és a sertésből készült termékek vásárlásával és fogyasztásával szemben támasztott preferenciákban.

\section{Anyag és módszer}

A tanulmány egy a Debreceni Egyetem Gazdaságtudományi Karának hallgatói körében, 2019. októbernovemberben megvalósult kérdőíves felmérésen alapszik. Az adatfelvétel online, önkitöltős formában történt. A részvétel önkéntes és anonim volt. A kényelmi mintavételi eljárás miatt a vizsgált minta nem reprezentatív, ezért a kutatás eredményeinek általánosíthatósága korlátozott.

A kérdőív két részből állt. Az elsőben a sertéshús és a sertésből készült termékek fogyasztásával és vásárlásával, míg a másodikban a demográfiai jellegű információkkal kapcsolatos kérdések kaptak helyet. Utóbbi leíró statisztikáit és a változók kódolását az 1. táblázat szemlélteti.

\begin{tabular}{|c|c|c|c|}
\hline Változók & \multicolumn{2}{|c|}{ Minta $(\mathrm{N}=324)$} & Kódolás \\
\hline $\begin{array}{l}\text { Nem (\%) } \\
\text { Férfi } \\
\text { Nő }\end{array}$ & \multicolumn{2}{|c|}{$\begin{array}{l}30,9 \\
69,1\end{array}$} & $\begin{array}{c}\text { kategorikus változó } \\
\text { (0 - Férfi, } \\
1-\text { Nő })\end{array}$ \\
\hline Életkor (év) & $\begin{array}{l}\text { átlag } \\
21,07\end{array}$ & $\begin{array}{c}\text { szórás } \\
3,53\end{array}$ & folytonos változó \\
\hline $\begin{array}{c}\text { Legmagasabb iskolai végzettség (\%) } \\
\text { középfokú végzettség } \\
\text { felsőfokú végzettség }\end{array}$ & \multicolumn{2}{|c|}{$\begin{array}{l}83,0 \\
17,0\end{array}$} & $\begin{array}{c}\text { kategorikus változó } \\
\text { (0 - középfokú végzettség, } \\
1 \text { - felsőfokú végzettség) }\end{array}$ \\
\hline $\begin{array}{l}\text { Lakhely }(\%) \\
\qquad \begin{array}{l}\text { község } \\
\text { kisváros } \\
\text { nagyváros } \\
\text { megyeszékhely }\end{array}\end{array}$ & \multicolumn{2}{|c|}{$\begin{array}{l}18,5 \\
40,4 \\
11,1 \\
30,0\end{array}$} & $\begin{array}{l}\text { kategorikus változó } \\
\text { (0 - község, } \\
1 \text { - kisváros, } \\
\text { 2 - nagyváros, } \\
\text { 3 - megyeszékhely) }\end{array}$ \\
\hline A háztartásban élők száma (fő) & $\begin{array}{c}\text { átlag } \\
3,71\end{array}$ & $\begin{array}{c}\text { szórás } \\
1,02\end{array}$ & folytonos változó \\
\hline $\begin{array}{l}\text { A háztartás havi nettó (1 főre jutó) } \\
\text { jövedelme (\%) } \\
\text { nem szeretnék válaszolni } \\
\text { kevesebb, mint } 100 \text { ezer Ft } \\
100-200 \text { ezer Ft } \\
200-300 \text { ezer Ft } \\
\text { több, mint } 300 \text { ezer Ft }\end{array}$ & \multicolumn{2}{|c|}{$\begin{array}{l}19,8 \\
10,8 \\
32,7 \\
22,2 \\
14,5\end{array}$} & $\begin{array}{c}\text { kategorikus változó } \\
\text { (0 -nem szeretnék válaszolni, } \\
\begin{array}{c}1 \text { - kevesebb, mint } 100 \text { ezer } \mathrm{Ft}, \\
2-100-200 \text { ezer } \mathrm{Ft}, \\
3-200-300 \text { ezer } \mathrm{Ft}, \\
4 \quad \text { több, mint } 300 \text { ezer } \mathrm{Ft})\end{array}\end{array}$ \\
\hline
\end{tabular}

1. táblázat. A megkérdezettek demográfia jellegü adatai

Forrás: Saját szerkesztés

Az elemzések elkészítéséhez az IBM SPSS Statistics 25 és a Microsoft Office Excel 2016 programokat használtam fel. Az adatok feldolgozása során a leíró statisztikai módszerek mellett megoszlási 
viszonyszámokat, Khi-négyzet próbákat és Spearman-féle rangkorreláció számítást végeztem. A vizsgálni kívánt kimeneti változók mérési szintje (ordinális) és a nominalitás feltételének sérülése miatt, (Kolmogorov-Smirnov teszttel ellenőrizve) a különböző csoportok közötti eltérések vizsgálatához Mann-Whitney és Kruskal-Wallis próbákat alkalmaztam.

\section{Eredmények}

A sertéshús és a sertésből készült termékek fogyasztásával és vásárlásával kapcsolatos kérdésekre adott válaszok alapján az alábbi megállapítások születtek a vizsgált mintára vonatkozóan.

A megkérdezettek 40,1\%-a válaszolta azt, hogy húsfogyasztásának kevesebb, mint 30\%-át teszi ki a sertéshús; 49,1\%-a felelte, hogy 30-60\%-át; míg 10,8\%-ának több, mint a húsfogyasztásának 60\%-a sertéshús. A vásárlás helyszínét tekintve a megkérdezettek/családjuk 46,3\%-a hentesnél vásárol, 29,0\%-a szupermarketben/hipermarketben, 13,3\%-a termelőtől/piacon, 8,3\%-a kisboltban és 3,1\%-a nem vásárol sertéshúst.

A következő kérdés arra irányult, hogy a sertés mely részeit fogyasztják szívesen a válaszadók. Itt több alternatívát is meg lehetett jelölni. Az összesített eredmények alapján a válaszadók 85,5\%-a fogyaszt karajt, 72,2\%-a tarját, 66,0\%-a oldalast, 57,5\%-a combot, 34,3\%-a csülköt, 34\%-a lapockát és 12,7\%-a dagadót.

A sertésből készült termékek fogyasztására vonatkoztatva, az előző kérdéshez hasonló felépítésben, a következő eredmények születtek. A kitöltők 80,9\%-a fogyaszt virslit, 79,6\%-a sonkát, 75,0\%-a szalámit, 72,8\%-a kolbászt, 67,6\%-a májkrémet/pástétomot, 66,7\%-a szalonnát, 60,5\%-a párizsit/felvágottat, 43,5\%-a tepertőt, 34,6\%-a zsírt és 15,1\%-a disznósajtot.

A következő kérdés arra irányult, hogy a válaszadók az egyes szempontokat (ár, termék összetevői, zsírtartalom, egészséges táplálkozás, frissesség, magyar termék, gyártó/márka, kiszerelés/csomagolás) mennyire tartják fontosnak a vásárlásaik során. Az egyes tényezők fontosságát ötfokozatú skálán (1 egyáltalán nem fontos, 5 - nagyon fontos) kellett megjelölni. Ordinális mérési szintû változók lévén a szempontokhoz tartozó módusz és medián értékek kerültek meghatározásra, amelyeket a 2. táblázat mutat be.

\begin{tabular}{|l|c|c|}
\hline \multicolumn{1}{|c|}{ Szempontok } & Módusz & Medián \\
\hline frissesség & 5 & 5 \\
\hline magyar termék & 5 & 4 \\
\hline termék összetevői & 5 & 4 \\
\hline ár & 4 & 4 \\
\hline gyártó/márka & 4 & 4 \\
\hline kiszerelés/csomagolás & 4 & 4 \\
\hline zsírtartalom & 3 & 4 \\
\hline egészséges táplálkozás & 3 & 4 \\
\hline
\end{tabular}

2. táblázat. A vásárlásnál figyelembe vett tényezők leíró statisztikái

Forrás: Saját szerkesztés 
A válaszadók által adott leggyakoribb érték a frissességre, a magyar termékre és a termék összetevőire vonatkozóan öt, az árra, a gyártóra/márkára és a kiszerelésre/csomagolásra vonatkozóan négy, míg a zsírtartalomra és az egészséges táplálkozásra vonatkozóan három volt.

Napjainkban egyre nagyobb jelentősége van a magyar termékek vásárlásának és az egészségtudatosságnak, ezért a kérdőívben megkérdezésre került, hogy a vásárlók mennyivel hajlandóak többet fizetni a magyar, illetve az egészségesebb termékekért (Vida-Szúcs, 2016; BarcsJenes, 2017). Az 1. ábra azt kívánja szemléltetni, hogy a válaszadók hány százalékkal hajlandóak többet fizetni a magyar termékekért.

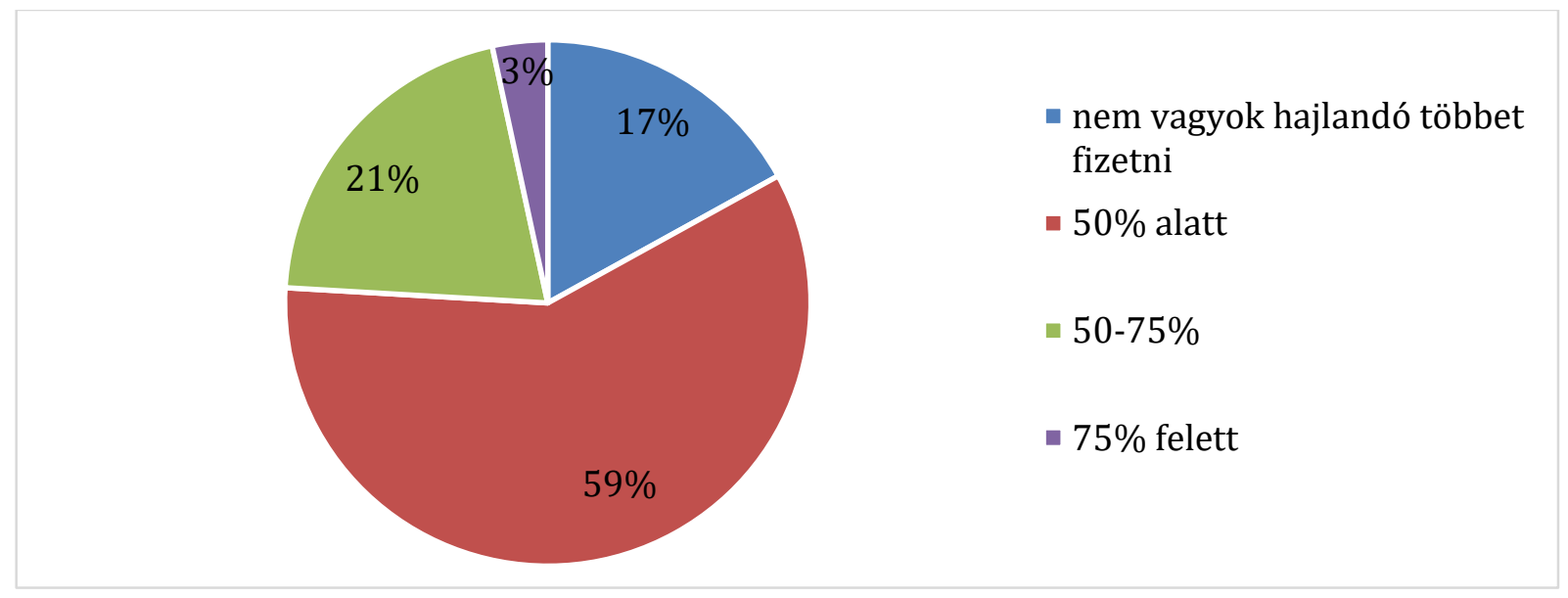

1. ábra. A magyar termékre vonatkozó fizetési hajlandóság vizsgálatának eredménye Forrás: Saját szerkesztés

A diagramon látható, hogy a válaszadók 59\%-a 50\% alatti összeggel, 21\%-a 50-75\% közöttivel, 17\%-a nem hajlandó többet fizetni és mindössze 3\%-a lenne hajlandó 75\% feletti összeggel többet fizetni a magyar termékekért.

A 2. ábra mutatja be, hogy a fogyasztók hány százalékkal fizetnének többet az egészségesebb termékekért.

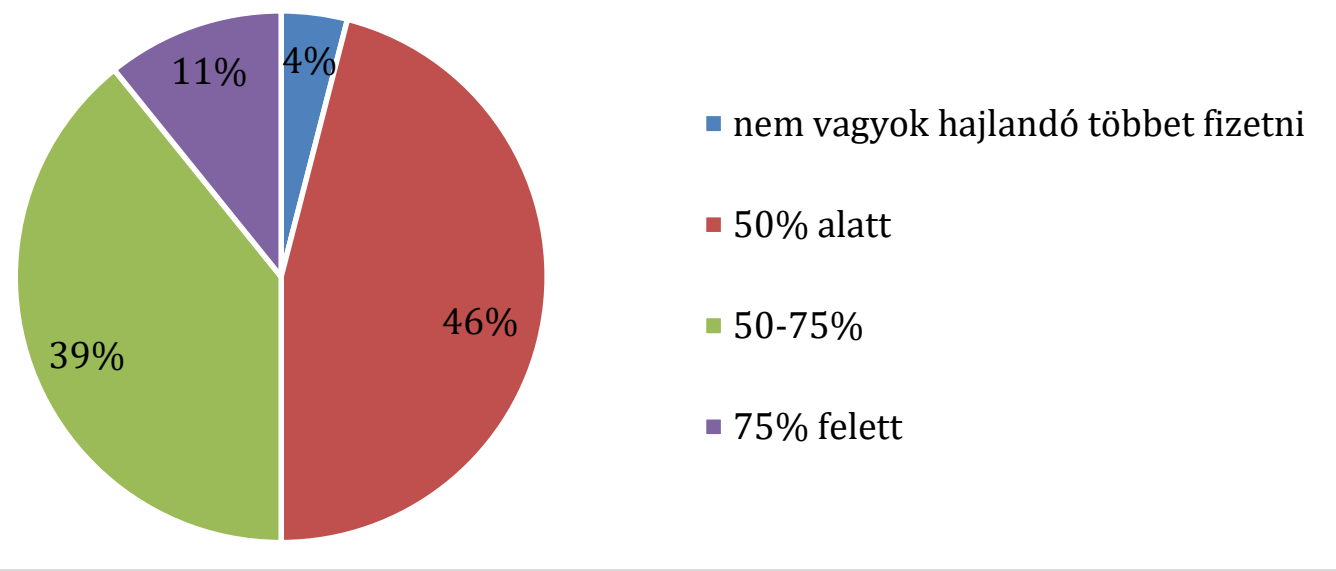

2. ábra: Az egészségesebb termékre vonatkozó fizetési hajlandóság vizsgálatának eredménye Forrás: Saját szerkesztés 
A diagramon alapján elmondható, hogy a kitöltők 46\%-a 50\% alatti összeggel lenne hajlandó többet fizetni, 39\%-a 50-75\% közötti, 11\%-a 75\% felettivel és 4\%-a nem lenne hajlandó többet fizetni az egészségesebb termékekért.

A továbbiakban Khi-négyzet próbákat végeztem a demográfiai jellegű adatok és a sertés egyes részeinek, valamint a sertéshúsból készült termékek fogyasztása közötti kapcsolat vizsgálata érdekében. A szignifikáns eredmények a 3. táblázatban láthatók. A 2x2-es tábláknál a Phi érték, ennél nagyobb táblák esetében a Cramer féle asszociációs együttható értéke lett meghatározva.

\begin{tabular}{|c|c|c|}
\hline & $\chi^{2}$ & Phi/Cramer \\
\hline nemek - szalámi & $7,714^{* *}$ & $0,154^{* *}$ \\
\hline nemek - májkrém, pástétom & $4,875^{* *}$ & $0,123^{* *}$ \\
\hline lakhely - hol vásárol & $27,635^{* *}$ & $0,169^{* *}$ \\
\hline iskolai végzettség - karaj & $4,376^{* *}$ & $0,116^{* *}$ \\
\hline iskolai végzettség - comb & $6,117^{* *}$ & $0,137^{* *}$ \\
\hline lakhely - májkrém & $9,677^{* *}$ & $0,173^{* *}$ \\
\hline lakhely - karaj & $7,821^{* *}$ & $0,155^{* *}$ \\
\hline
\end{tabular}

** 5\%-os szinten szignifikáns

\section{3. táblázat. A Khi-négyzet próbák eredményei}

Forrás: Saját szerkesztés

A Khi-négyzet próbák eredményei alapján statisztikailag igazolható, hogy a férfiak közül többen fogyasztanak szalámit, a nők közül pedig többen fogyasztanak májkrémet. A vásárlás helyét tekintve kisboltban szignifikánsan több kisvárosban élő vásárol, mint megyeszékhelyen élő; szupermarketben/hipermarketben viszont igazolhatóan több megyeszékhelyen élő vásárol, mint községben élő. A sertéshúst és sertésből készült termékeket nem vásárlók esetén statisztikailag igazolhatóan többen vannak a községben, mint a megyeszékhelyen élők. Az iskolai végzettséget tekintve a felsőfokú végzettséggel rendelkezők közül igazolhatóan többen fogyasztanak karajt és combot, a középfokú végzettséggel rendelkezők közül pedig szignifikánsan kevesebben. A lakhely tekintetében a megyeszékhelyen élők közül statisztikailag igazolhatóan többen fogyasztanak májkrémet, a kisvárosban élők közül pedig kevesebben. Karajt pedig a nagyvárosban élők közül szignifikánsan kevesebben fogyasztanak.

\begin{tabular}{|c|c|c|c|c|c|c|c|c|}
\hline & $\dot{\nabla}$ & 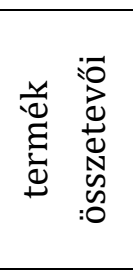 & 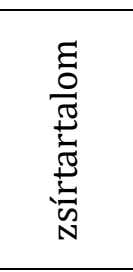 & 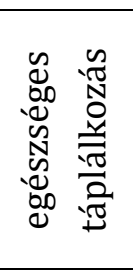 & 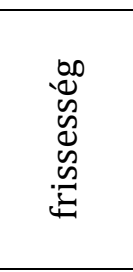 & 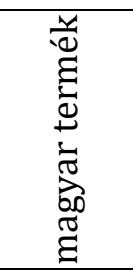 & 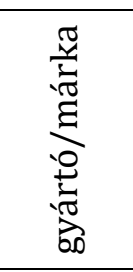 & 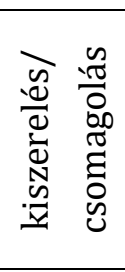 \\
\hline ár & 1,000 & ,124** & ,178** & 0,101 & 0,086 & $-0,051$ & 0,039 & ,219** \\
\hline $\begin{array}{l}\text { termék } \\
\text { összetevői }\end{array}$ & ,124** & 1,000 & ,415** & ,399** & ,345** &, $281^{* *}$ & ,180** &, $112 * *$ \\
\hline
\end{tabular}




\begin{tabular}{|c|c|c|c|c|c|c|c|c|}
\hline zsírtartalom & ,178** & ,415** & 1,000 & ,572** & ,170** & ,162** & 0,078 & ,178** \\
\hline $\begin{array}{l}\text { egészséges } \\
\text { táplálkozás }\end{array}$ & 0,101 & ,399** &, $572 * *$ & 1,000 & ,184** & ,138** & 0,091 &, $144^{* *}$ \\
\hline frissesség & 0,086 & ,345** & ,170** & ,184** & 1,000 & ,343** & ,232** & ,237** \\
\hline magyar termék & $-0,051$ & ,281** & ,162** & ,138** & ,343** & 1,000 & ,430** & ,253** \\
\hline gyártó/márka & 0,039 & ,180** & 0,078 & 0,091 & ,232** & ,430** & 1,000 & ,521** \\
\hline $\begin{array}{l}\text { kiszerelés/ } \\
\text { csomagolás }\end{array}$ & ,219** &, $112 * *$ & ,178** &, $144^{* *}$ &, $237^{* *}$ &, $253^{* *}$ &, $521 * *$ & 1,000 \\
\hline
\end{tabular}

** 5\%-os szinten szignifikáns

\section{4. táblázat. A korrelációs együtthatók értékei}

Forrás: Saját szerkesztés

Mivel a vásárlásnál figyelembe vett tényezők ordinális mérési szintű változók, ezért az egyes szempontok együttjárásának vizsgálatához a Spearman-féle rangkorrelációt alkalmaztam. A korrelációs együtthatók értékeit a 4. táblázat tartalmazza. Az eredmények alapján jól látható, hogy a tényezők döntő többsége gyenge erősségű, pozitív korrelációt mutat egymással. Ezek közül kiemelhető a zsírtartalom és a termék összetevői, a zsírtartalom és az egészséges táplálkozás, a gyártó/márka és a magyar termék, valamint a gyártó/márka és a kiszerelés/csomagolás közötti, már közepes erősségűnek tekinthető kapcsolat.

A továbbiakban azt vizsgáltam, hogy a sertésből készült termékeket fogyasztó férfiak és nők, valamint a középfokú és a felsőfokú végzettséggel rendelkező csoportok között van-e eltérés a vásárlásnál figyelembe vett tényezők fontosságának tekintetében. A kimeneti változó mérési szintje és a normalitás feltételének sérülése miatt alkalmazott Mann-Whitney tesztek eredményeit, az 5. és 6. táblázat tartalmazza.

\begin{tabular}{|l|c|c|c|}
\hline \multirow{2}{*}{\multicolumn{1}{|c|}{ Szempont }} & \multicolumn{2}{c|}{ Rangátlagok } & \multirow{2}{*}{ Z érték } \\
\cline { 2 - 3 } & férfi & nő & \\
\hline ár & 136,28 & 174,21 & $-3,538^{* *}$ \\
\hline termék összetevői & 141,45 & 171,90 & $-2,925^{* *}$ \\
\hline zsírtartalom & 145,29 & 170,18 & $-2,309^{* *}$ \\
\hline egészséges táplálkozás & 141,08 & 172,06 & $-2,867^{* *}$ \\
\hline frissesség & 143,83 & 170,84 & $-3,650^{* *}$ \\
\hline magyar termék & 139,86 & 172,61 & $-3,066^{* *}$ \\
\hline gyártó/márka & 139,66 & 172,70 & $-3,068^{* *}$ \\
\hline kiszerelés/csomagolás & 137,96 & 173,46 & $-3,277^{* *}$ \\
\hline
\end{tabular}

** 5\%-os szinten szignifikáns

5. táblázat. A Mann-Whitney teszt eredményei a nemek vonatkozásában Forrás: Saját szerkesztés

A táblázatból jól látható, hogy a vizsgált szempontok (ár, termék összetevői, zsírtartalom, egészséges táplálkozás, frissesség, magyar termék, gyártó/márka, kiszerelés/csomagolás) mindegyikénél szignifikáns eltérés mutatkozik, továbbá a nők számára fontosabbak a tényezők. 


\begin{tabular}{|l|c|c|c|}
\hline \multirow{2}{*}{ Szempont } & \multicolumn{2}{c|}{ Rangátlagok } & \multirow{2}{*}{ Z érték } \\
\cline { 2 - 3 } & Középfokú végzettség & Felsőfokú végzettség & \\
\hline ár & 162,05 & 164,69 & $-0,200$ \\
\hline termék összetevői & 162,93 & 160,39 & $-0,198$ \\
\hline zsírtartalom & 166,40 & 143,45 & $-1,730$ \\
\hline egészséges táplálkozás & 166,24 & 144,19 & $-1,658$ \\
\hline frissesség & 162,68 & 161,64 & $-0,114$ \\
\hline magyar termék & 158,29 & 183,07 & $-1,885$ \\
\hline gyártó/márka & $\mathbf{1 5 7 , 1 1}$ & $\mathbf{1 8 8 , 8 7}$ & $\mathbf{- 2 , 3 9 8 * *}$ \\
\hline kiszerelés/csomagolás & 158,33 & 182,89 & $-1,842$ \\
\hline
\end{tabular}

** 5\%-os szinten szignifikáns

6. táblázat. A Mann-Whitney teszt eredményei a végzettségek vonatkozásában

Forrás: Saját szerkesztés

A 6. táblázatból jól látható, hogy iskolai végzettség szerint mindössze a gyártó/márka tekintetében mutatkozik szignifikáns eltérés a középfokú és felsőfokú végzettséggel rendelkező csoportok között, ahol a felsőfokú végzettséggel rendelkezők esetében nagyobb a rangátlag.

A háztartás havi nettó egy főre jutó jövedelme szerinti csoportok eltéréseinek vizsgálatához KruskalWallis tesztet alkalmaztam, melynek eredményeit a 7. táblázat szemlélteti.

\begin{tabular}{|l|c|c|c|c|c|}
\hline \multirow{2}{*}{ Szempont } & \multicolumn{4}{|c|}{ Rangátlagok } & \multirow{2}{*}{ H érték } \\
\cline { 2 - 5 } & $\begin{array}{c}\text { Kevesebb, } \\
\text { mint 100 } \\
\text { ezer forint }\end{array}$ & $\begin{array}{c}100-200 \\
\text { ezer forint }\end{array}$ & $\begin{array}{c}200-300 \\
\text { ezer forint }\end{array}$ & $\begin{array}{c}\text { Több, mint } \\
\text { 300 ezer } \\
\text { forint }\end{array}$ & \\
\hline ár & $\mathbf{1 5 9 , 2 9}$ & $\mathbf{1 3 8 , 0 2}$ & $\mathbf{1 2 4 , 8 7}$ & $\mathbf{1 0 0 , 7 3}$ & $\mathbf{1 5 , 4 7 1 * *}$ \\
\hline termék összetevői & 116,14 & 131,26 & 138,65 & 126,99 & 2,622 \\
\hline zsírtartalom & 110,87 & 137,38 & 135,42 & 122,07 & 4,536 \\
\hline egészséges táplálkozás & $\mathbf{1 0 9 , 2 9}$ & $\mathbf{1 2 9 , 2 3}$ & $\mathbf{1 5 5 , 1 9}$ & $\mathbf{1 1 1 , 3 3}$ & $\mathbf{1 4 , 7 7 4 * *}$ \\
\hline frissesség & 122,54 & 128,75 & 136,46 & 131,26 & 2,098 \\
\hline magyar termék & 113,93 & 126,38 & 136,67 & 142,68 & 4,148 \\
\hline gyártó/márka & 114,73 & 126,86 & 135,53 & 142,74 & 3,668 \\
\hline kiszerelés/csomagolás & 121,97 & 135,82 & 133,99 & 119,51 & 2,312 \\
\hline
\end{tabular}

** 5\%-os szinten szignifikáns

7. táblázat. A Kruskal-Wallis teszt eredményei

Forrás: Saját szerkesztés

A táblázat eredményei alapján jól látható, hogy két tényező, az ár és az egészséges táplálkozás tekintetében mutatható ki szignifikáns eltérés a jövedelemkategóriák szerinti csoportok között. Szintén Kruskal-Wallis próbát alkalmaztam annak vizsgálatára, hogy a lakhely szerinti kategóriák között mutatható-e ki eltérés a szempontok szerint, azonban ebben az esetben nem szültetett szignifikáns eredmény. 


\section{Összefoglalás}

A kutatás középpontjában a sertéshús és a sertésből készült termékek vásárlásával és fogyasztásával kapcsolatos preferenciák vizsgálata állt. Célom volt megvizsgálni, hogy mutatható-e ki eltérés a különböző, többnyire demográfiai változók mentén csoportosított fogyasztói rétegek között, a sertéshússal és a sertésből készült termékekkel kapcsolatos megítélésben.

Az adatgyűjtés a Debreceni Egyetem Gazdaságtudományi Karán zajlott 2019 őszén, ahol a mintába bevont hallgatók online kérdőíves formában lettek megkérdezve. Az adatok feldolgozása az SPSS Statistics 25 program segítségével történt. Az elemzés során alkalmazásra kerültek leíró statisztikai módszerek, Khi-négyzet próbák, Spearman-féle rangkorreláció számítás, Mann-Whitney és KruskalWallis próbák.

A kérdőívet kitöltők mindegyike fogyaszt sertéshúst és sertésből készült termékeket. Az elemzésekből nyert információk alapján azok a következtetések vonhatók le, hogy a vizsgált mintában szereplő fogyasztók többsége, mindössze 50\% alatti összeggel fizetne többet a magyar és az egészségesebb termékekért. A Khi-négyzet próbák eredményei szerint kapcsolat mutatható ki a nem, a végzettség, a lakhely és a sertéshús bizonyos részei, valamint néhány sertésből készült termék fogyasztása között. Szükséges szót ejteni arról, hogy a vizsgálatba bevont vásárlásnál figyelembe vett szempontok között túlnyomó többségben gyenge, pozitív irányú korreláció áll fenn, amelyek közül 0,5-ös értékhez közeli erősségével kiemelhető a zsírtartalom és a termék összetevői, a zsírtartalom és az egészséges táplálkozás, a gyártó/márka és a magyar termék, valamint a gyártó/márka és a kiszerelés/csomagolás közötti kapcsolat. A Mann Whitney és a Kruskal-Wallis tesztek alapján pedig azok a következtetések tehetők, hogy a férfiak és nők között szignifikáns eltérés van jelen minden vásárlásnál figyelembe vett tényező tekintetében; a középfokú és a felsőfokú végzettséggel rendelkezők csoportjai között jelentős eltérést mutatható ki a gyártó/márka megítélésében, míg a jövedelemkategória csoportok között az ár és az egészséges táplálkozás szerint van jelentős eltérés.

A kutatás korlátai között meg kell említeni, hogy az elemzésbe bevont minta nem reprezentatív, az eredmények ezért nem általánosíthatók, viszont iránymutatást nyújthatnak jövőbeni vizsgálatokhoz.

Köszönetnyilvánítás: „Ez a kutatás a Nemzeti Kutatási, Fejlesztési és Innovációs (NKFI) Hivatal KH-18. 130443 sz. pályázatából valósult meg."

\section{Hivatkozások}

[1] AKI (2019): A sertéshús külkereskedelmének mennyisége és értéke (2004-2018). https://sertesinfo.aki.gov.hu/publikaciok/publikacio/a:747/A+sert\%C3\%A9sh\%C3\%BAs+k\%C 3\%BClkereskedelm\%C3\%A9nek+mennyis\%C3\%A9ge+\%C3\%A9s+\%C3\%A9rt\%C3\%A9ke+(20 04-2018), letöltés dátuma: 2020. január 5.

[2] Aydogdu, M. - Kucuk, N. (2018): General Analysis of Recent Changes in Red Meat Consumption in Turkey. IOSR Journal of Economics and Finance. 2018. 9 (6) 1-8. 
[3] Barcs, J. - Jenes, B. (2017): Funkcionális élelmiszerek növekvő népszerűsége - a hazai cereáliapiac fogyasztói megítélése. Táplálkozásmarketing. 2017. 4 (1-2) 23-37.

[4] Bernabéu, R. - Rabadán A. - El Orche, N.E. - Díaz, M. (2018): Influence of quality labels on the formation of preferences of lamb meat consumers. A Spanish case study. Meat Science. 2018. 135 129-133.

[5] Boland, L.A. (2017): Equilibrium Models in Economics: Purposes and Critical Limitations. United States of America Oxford University Press, New York. 2017.

[6] Csonka A. (2012): Strukturális folyamatok a vágósertés-piacon az EU-csatlakozás után. KözépEurópai Közlemények. 4:2.115-122.

[7] Demartini, E. - Vecchiato, D. - Tempesta, T. - Gaviglio, A. - Viganó, R. (2018): Consumer preferences for red deer meat: a discrete choice analysis considering attitudes towards wild game meat and hunting. Meat Science. 2018. 146 168-179.

[8] Keeney, R.L. - Raiffa, H. (1993): Decisions with Multiple Objectives. Cambridge University Press, Cambridge. 1993.

[9] Kiran, M. - Prabhu Nithin, K. - Paramesha, S.C. - Rajshekar, T. - Praveen, M.P. - Punitkumar, C. Puneetha, S.C. - Kumar, R. - Rahul, J. - Nagabhushan, C. (2018): Consumption pattern, consumer attitude and consumer perception on meat quality and safety in Southern India. International Food Research Journal. 2018. 25 (3) 1026-1030.

[10] Kotler, P. (1998): Marketing menedzsment. Műszaki Könyvkiadó, Budapest. 1998.

[11] KSH (2019a): Szarvasmarha-, sertés-, ló- és juhállomány (1851-). letöltés helye: https://www.ksh.hu/docs/hun/agrar/html/tabl1_5_1_1.html?fbclid=IwAR2IYNtIzU1sT_0i9C06 vm3g5CUsT0mZV-CqyhGDqgpMZwDZH9BLCK7tvgk, letöltés dátuma: 2020. január 5.

[12] KSH (2019b): A rendelkezésre álló élelmiszerek egy főre jutó mennyisége (1970-). letöltés helye: https://www.ksh.hu/docs/hun/xstadat/xstadat_hosszu/elm14.html, letöltés dátuma: 2019. november 15.

[13] KSH (2019c): Baromfihúsmérleg (1970-). letöltés helye: https://www.ksh.hu/docs/hun/xstadat/xstadat_hosszu/elm07.html, letöltés dátuma: 2019. november 15.

[14] $\mathrm{KSH}$

(2019d): $\quad$ Sertéshúsmérleg

(1970-). letöltés helye: https://www.ksh.hu/docs/hun/xstadat/xstadat_hosszu/elm01.html, letöltés dátuma: 2019. november 15.

[15] Lambooij, M.S. - Veldwijk, J. - van Gils, P. - Mangen, M.J. - Over, E. - Suijkerbuijk, A. - Polder, J. de Wit, G.A. - Opsteegh, M. (2019): Consumers preferences for freezing of meat to prevent toxoplasmosis - A stated preference approach. Meat Science. 2019. 149 1-8.

[16] Merlino, V.M. - Borra, D. - Girgenti V. - Dal Vecchio, A. - Massaglia S. (2018): Beef meat preferences of consumers from Northwest Italy: Analysis of choice attributes. Meat Science. 2018. 143 119128. 
[17] Mousavi, S. (2018): Book Review: Handbook of the Economics of Risk and Uncertainty. Frontiers in Psychology. 2018. 9730.

[18] Ngapo, T.M. - Rubio Lozano, M.S. - Brana Varela, D. (2018): Mexican consumers at the point of meat purchase. Pork choice. Meat Science. 2018. 135 27-35.

[19] Sharma, J. (2018): Economics of Decision Making: Exploring Analytical Hierarchical Process (AHP). Theoretical Economics Letters. 2018.8 (14) 3141-3156

[20] Torrico, D.D. - Hutchings, S.C. - Ha, M. - Bittner E.P. - Fuentes, S. - Warner, R.D. - Dunshea, F.R. (2018): Novel techniques to understand consumer responses towards food products: A review with a focus on meat. Meat Science. 2018. 144 30-42.

[21] Udomkun, P. - Ilukor, J. - Mockshell, J. - Mujawamariya, G. - Okafor, C. - Bullock, R. - Nabahungu, N.L. - Vanlauwe, B. (2018): What are the key factors influencing consumers preference and willingness to pay for meat products in Eastern DRC? Food Science \& Nutrition. 2018. 6 (8) 23212336.

[22] Vida, V. - Szűcs, I. (2016): A sertéshúsfogyasztási szokások vizsgálata a 4P alapján - a termékkel kapcsolatos kérdések bemutatása. The Hungarian Journal of Food Nutrition and Marketing. 2016. 12 (2) 47-54.

[23] Wang, H.H. - Chen, J. - Bai, J. - Lai, J. (2018): Meat packaging, preservation, and marketing implications: Consumer preferences in an emerging economy. Meat Science. 2018. 145 300-307.

[24] White, D.J. (2006): Decision Theory. Transaction Publishers, New Jersey. 2006. 